\title{
$\hat{I j} \hat{j} \hat{z}$ of Al-Qur'an in Perspective of An Noursi and Its Implication Towards the Translation of Al-Qur'an
}

\author{
Yusuf Baihaqi \\ The Science of Al-Qu'an and Tafseer Study Program UIN Raden Intan Lampung, Indonesia
}

\section{Article History:}

Received : July 02, 2019

Revised : August 09, 2019

Accepted : September 06, 2019

Published : December 01, 2019

Keywords:

Miracles; Moderate; Tarjamah

Tafsîriyyah; Turkey

*Correspondence Address:

yusuf.baihaqi@radenintan.ac.id

\begin{abstract}
There was a debate among the scholars regarding whether Al-Qur'an text was possible to be translated or not. When Al-Qur'an text is translated, another problem arises, whether the translation has included the entire meaning contained in Al-Qur'an text. So, it whether can replace the position of Al-Qur'an text or not. This paper aims to address these problems in An Noursi's perspective. Based on a descriptive analytical literature review of the writings of An Noursi relating to Al-Qur'an and the translation of Al-Qur'an, a conclusion can be drawn that the An Noursi is classified by Ulama that the text of Al-Qur'an cannot be translated into any language. This perspective is clearly seen when he explained the theme of Al-Qur'an, where Al-Qur'an is an aspect of the miracles of the language possessed by Al-Qur'an and cannot be possessed and compared by any other language. In addition, An Noursi's rejection of Al-Qur'an translation above cannot be separated from the social political influence in Turkey at that time, where religious secularization was very intensively carried out by the authorities. In other words, this paper tries to present a moderate perspective about the translation of Al-Qur'an, where the process of translating Al-Qur'an is very possible when the translation is understood to be limited to Tarjamah Tafsîriyyah not Tarjamah Harfiyyah, because actually the translation of Al-Qur'an is intended by the Ulama the one who rejected it was Tarjamah Harfiyyah. Besides, the translation of Al-Qur'an meant by the Ulama who allowed it was Tarjamah Tafsîriyyah.
\end{abstract}

\section{Introduction}

Debate around the translation of Al-Qur'an still frequently arises, between what is permissible and what is prohibited. As a product of the translation of Al-Qur'an whether it can cover the entire content of the meaning of Al-Qur'an or not also appears along with the perspective that allows us to replace the reading of Al-Qur'an with the translation product with a perspective that prohibits it. Examining the theme of Al-Qur'an in the perspective of An Noursi, to be compared with other Ulama's perspective about the translation of Al-Qur'an is interesting to study as a contribution of thought to answer the above problems. $\hat{j} j \hat{a} z$ is an important part of the content of the language of Al-Qur'an, the 
figure of An Noursi is a bit of a Al-Qur'an reviewer who discusses many of the sides of Al-Qur'an contained in the text of Al-Qur'an. Some previous studies about An Noursi are:

First, a study entitled "Said Nursi's Theological Thoughts In The Light Of Sunni Doctrine". A study that presents An Noursi's theological thought in a sunni direction. Where in his writings, An Noursi often criticized other directions in theology, such as: the Mu'tazilah which argues that the inability of humans to bring such a Qur'an, is not only because of language factors, but because there is interference from God who does not want humans to challenge Al-Qur'an. ${ }^{1}$ This Mu'tazilah's perspective greatly contributes to the degradation of the miraculous aspects of the language of Al-Qur'an, because it does not appear to be due to internal factors in Al-Qur'an, namely: beauty and the depth of the meaning of the language of Al-Qur'an, humans and jinns are unable to bring such a Qur'an. But because of its external factors, namely: God's intervention. For this reason, An Noursi strongly opposed the Mu'tazilah perspective, and tried to prove aspects of the language of Al-Qur'an, including through his writings about $\hat{j} j \hat{a} z$ of $\mathrm{Al}$ Qur'an.

Secondly, the study of the nature of the $\hat{I j} \hat{a} z$ of Al Qur 'an in An Noursi's perspective entitled “Îjâz Al Qur'an 'Inda An Nursî Mafâhîm Wa Zhawâbith”. This study not only presents the miraculous aspects of Al-Qur' an language, but also other aspects of miracles. ${ }^{2}$ An Noursi is a figure who not only limits the miraculous aspects of Al-Qur'an to aspects of the language only, but there are many other aspects of the content of AlQur'an which were also mentioned by An Noursi in his works. This paper is part of the miraculous aspects of Al-Qur'an which are often studied by An Noursi in a number of his works, namely: relating to aspects of the language of Al-Qur'an, Moreover, the specific one, $\hat{I j} \hat{a} z$ of Al Qur'an that is the one of the aspects of Al-Qur'an language.

Third, a study about An Noursi's views on western civilization, entitled "Muslim Response to the West: A Comparative Study of Muhammad Abduh and Said Nursi". This study presents the figure of An Noursi as a moderate Muslim scholar who is not allergic to western civilization, evidenced by his efforts to harmonize knowledge that was born from western civilization with the text of Al-Qur'an. However, An Noursi also

\footnotetext{
${ }^{1}$ Mohd Safri Ali, 'Said Nursi's Theological Thoughts In The Light Of Sunni Doctrine', Pertanika Journal (Social Sciences \& Humanities), 25 (2017), pp. 71-78.

${ }^{2}$ Sa`ad Ahmad, 'I jâz Al Qur'ân `Inda An Nursî Mafâhîm Wa Zhawâbith', The Journal Of Risale-i Nur Studies, 1.1 (2018), pp. 106-21.
} 
does not accept western civilization as it is without criticism, such as: its rejection of secular ideology that was tried to be adopted in Turkey during Kamal Ataturk period. ${ }^{3}$ That is the way to translate the Holy Qur'an into Turkish. An effort that was strongly opposed by An Noursi, because Al-Qur'an is a holy book that contains miracles in terms of language, so Al-Qur'an cannot be replaced by any language. Moreover, the language of Al-Qur'an changed when it is read in a number of worship rituals.

Fourth, the study of An Noursi's perspective of modern science, entitled "AlQur'an Scientism In Bediuzzaman Said Nursi's Risala-I-Nur'. This study presents An Noursi's Inclusive thinking that seeks to integrate based on sharia science with sciencebased. ${ }^{4}$ Merging between sharia and science is a necessity, especially in this era, with notes the text of Al-Qur'an which is to be related to the achievements of science, must not be in conflict with the denotation of the language of Al-Qur'an, as the science which is to be linked must have passed the stages of a number of experiments and agreed upon by the scientists.

Fifth, the study of An Noursi's socio-political movement and its contribution to Turkey and the world in an article titled "Transition in Turkey: An Overview of Badiuzzaman Said Nursi, His Life and Works for Medresetu'z-Zehra". ${ }^{5}$ Results from An Noursi's socio-political activities, not only felt during his life, but the results still exist until now, it is proven by the emergence of a number of notable people of modern and moderate Islamic thinkers and movements in Turkey.

Those are the five previous studies about An Noursi and certainly have relevance to this study, and what distinguishes these studies from this study is that this study specifically discusses An Noursi's perspective on the side of Al-Qur'an, and the implications this perspective has for Al-Qur'an translation. For a number of reasons above, this study was written, hopefully this article can provide enlightenment about the miracle aspects of Al-Qur'an in terms of its $\hat{I j} \hat{a} z$, and encourage us more to study the content of the language of Al-Qur'an, and be more careful in translating every part of the text of Al-Qur'an, so as not to reduce the beauty and depth of meaning contained therein.

${ }^{3}$ Hamid Zubair, 'Muslim Response To The West: A Comparative Study Of Muhammad Abduh and Said Nursi', Journal Of Islamic Thougt and Civilization, 4.2 (2014), pp. 01-08.

4 Ali Muhammad, 'Qur'anic Scientism In Bediuzzaman Said Nursi's Risala-I-Nur', Qudus International Journal Of Islamic Studies, 5.1 (2017), pp. 1-24.

${ }^{5}$ Kamaruzzaman Yusoff, 'Transition In Turkey: An Overview Of Badiuzzaman Said Nursi, His Life and Works For Medresetu'z-Zehra', International Journal Of West Asian Studies, 5.2 (2013), pp. 6777. 
Because translating Al-Qur'an in Harfiyyah is not possible in any language, what can be done is limited to the translation of the Tafsiriyyah.

\section{Theoretical Support}

This study is based on the theory that Al-Qur'an was revealed in Arabic, ${ }^{6}$ Arabic used by Al-Qur'an is not just any Arabic, but Arabic which has a number of advantages that make anyone unable to match and bring something like him. Another theory also states that Al-Qur'an is a holy book that contains miracles, the character of a miracle is that it cannot be matched. The advantages of this Qur'an have implications for the process of not transferring the full meaning of the contents into another language (Tarjamah Harfiyyah), because when it is possible, then the challenge is to bring in such things, and the miracle aspects are lost. he has. ${ }^{7}$

\section{Method}

This study is part of the Library Research, in terms of presentation is analytical descriptive, while the analysis method is used with a qualitative approach. This analysis is intended to describe Al-Qur'an in the An Noursi's perspective by presenting a number of concrete examples of his views about Al-Qur'an's Qur'an and its implications for his views about the translation of Al-Qur'an, compared with other Ulama (theologian) views, then accompanied by analysis of what lies behind his perspective of translating Al-Qur'an.

The technique of data collection is by literature study, both primary literature and directly related to the theme of the study, such as: An Noursi's works relating to AlQur'an and his perspective of the translation of Al-Qur'an, and secondary literature, not directly related but have relevance to the theme of the study, such as a number of writings relating to the language of Al-Qur'an and a number of aspects of its miracles.

\section{Result and Discussion}

\section{Al-Îjâz is the Part of the Miraculous Aspects of the Language of Al-Qur'an}

\footnotetext{
${ }^{6}$ Al Qur'an (Jakarta: Kemenag RI, 2018), v. Q.S. Al Hijr [15]: 1.

${ }^{7}$ Al Qur'an, v. Q.S. Al Isra [17]: 88.
} 
Mu'jizat or miracle is as defined by many Ulama as an extraordinary event with challenges and free from resistance. ${ }^{8}$ The scholars agree that Al-Qur'an is part of the miracles given to the Prophet Muhammad, even his greatest miracles, ${ }^{9}$ because those who can feel the aspects of miracles are not only people who lived during the prophet Muhammad peace be upon him, but those of us who live not during his time can also feel it, when we want spend time to try to study it, it is not like what the Western observers have understood that Al-Qur'an is a holy book that is difficult to understand, ${ }^{10}$ even the miracle aspects of Al-Qur'an will continue to apply until the end of life in this world whether for human being, and for all the other creations of Allah. ${ }^{11}$

Although the Ulama agree with regard to the miracles of Al-Qur'an, they disagree about the miracle aspects. However, there are 3 aspects of miracles that are often revealed by reviewers of Al-Qur'an: First, the language aspect. Secondly, the news aspect is unseen. Third, aspects of scientific cues. ${ }^{12}$ Al Alusi stated that there were 4 aspects of the miracles of Al-Qur'an. First, Nazhm (word order) of Al-Qur'an. Second, Balâghah (eloquence) of Al-Qur'an. Third, the supernatural preach of Al Qur'an. Fourth, the logic of Al-Qur'an. ${ }^{13}$

More concretely, Al Qurthubi mentions 10 aspects of miracles possessed by AlQur'an. First, the composition of the words is amazing and different from the arrangement of words that are owned by others, even different from Arabic although it has similarities with Al-Qur'an from the side of the letters. Second, the language style. Third, the assertiveness of the editor is impossible for any creature to express. Fourth, the accuracy of the placement of letters and words. Fifth, the news. Sixth, fulfillment of its promises, where every promise that Allah swt promises for his creatures is realized in the real world. Seventh, his predictions about unseen cases that will occur in the future.

\footnotetext{
${ }^{8}$ Mahir Hilal, 'Dirâyat al I'jâz Inda Fakhriddin al Râzi', Quranica: International Journal Of Quranic Research, 7a.Special Issue (2015), p. 90.

${ }^{9}$ Izzatul Laila, 'Penafsiran Al Qur'an Berbasis Ilmu Pengetahuan', Jurnal Epistemé, 9.1 (2014), p. 46.

${ }^{10}$ Masbukin, 'Kemu’jizatan Al Qur'an, Jurnal Pemikiran Islam', Jurnal Pemikiran Islam, 37.2 (2012), p. 171.

${ }^{11}$ Sharifah Syed and Ahmed Al Qodsi, 'The Manifestation Of Miraculous Effects Of The Quran On The Creatures From The Perspective Of Al-Quran, Hadits and Science', Quranica: International Journal Of Quranic Research, 9.2 (2017), p. 25.

${ }^{12}$ Abdurrahman, 'Mukjizat Al Qur'an Dalam Berbagai Aspeknya', Jurnal Pusaka, 8 (2016), p. 70.

13 Hilmy Muhammad, 'Nazhm Al Qur'an Dalam Perspektif Syihab al-Dīn al-Alūsī', Jurnal Refleksi, 13.6 (2014), p. 688.
} 
Eighth, science and law. Ninth, the noble values it has. Tenth, correlation between all of its contents. ${ }^{14}$

Apart from the diversity of the Ulama (theologian) in identifying aspects of the miracle of Al-Qur'an, they agreed that the language of Al-Qur'an is full of miracles. ${ }^{15}$ Not even a few of the Ulama are of the opinion that the miracle aspects of Al-Qur'an, but only limited to the aspects of language, as stated by Abdul Qahir Al Jurjani. ${ }^{16}$ Arabic uses many diction which is concise and appropriate to show an intention. ${ }^{17}$ This phenomenon in balaghah is known as Al Îjâz. It is undeniable, that Al $\hat{I j} \hat{a} z$ is one of the arts in balaghah, some even say that balaghah itself is identical to $\hat{I j a} z .{ }^{18}$ The phenomenon of $A l \hat{I j} \hat{a} z$ we find in many editions of Al-Qur'an, and some even say that balaghah itself is identical to Ijâz. Al-Qur'an is a part of the Al-Qur'an balaghah, where the Ulama agree to make the Balaghah aspect of Al-Qur'an as its miraculous aspect. On this basis balaghah, historically is one of the most important scientific disciplines in the interpretation of Al-Qur'an. ${ }^{19}$

\section{Ijjâz of Al Qur'an In An Noursi's Perspective}

An Noursi mentions seven (7) aspects of the great miracles possessed by AlQur'an. ${ }^{20}$ Among those seven aspects of miracles, six of them are included in the category of aspects of the language of Al-Qur'an, and the seventh is knowledge the knowledge contained in Al-Al-Qur'an content. Ijâz of Al Qur'an is one of the six aspects above. In An Noursi's view, seeing the miracle of Al-Qur'an does not have to look at AlQur'an as a whole, because the miracle is in every surah, even in every word. More than that, he also believed that we can feel the miracle of Al-Qur'an in each letter. ${ }^{21}$

An Noursi statement above is certainly not what is meant is the existence of letters or words themselves, without being associated with others, because the

\footnotetext{
${ }^{14}$ Abdullah Al Qurthubi, Al Jâmi`Li Ahkâm Al Qur'ân (Cairo: Dar Al Hadits, 2010), I, pp. 80-83.

${ }^{15}$ Mohamad Zaka, 'Aspek Relevansi Dalam Terjemahan Tindak-Tutur Kinâyah Al Qur'an', Jurnal Karsa (Journal Of Social and Islamic Culture), 21.2 (2013), p. 168.

16 Ach Thabrani, 'Nadzam Dalam I'jaz Al Qur'an Menurut Abdul Qahir Al Jurjani', Jurnal Al Mi yar, 1.1 (2018), p. 1.

${ }^{17}$ Azhar Muhammad, 'Beberapa Aspek Keunikan Dan Keistimewaan Bahasa Arab Sebagai Bahasa Al Qur'an', Jurnal Teknologi, 42 (2005), p. 67.

18 Jalaluddin As Suyuthi, Al Itqân Fî̀ Ulūm Al Qur'ân (Damaskus: Dar Ibnu Katsir, 2000), II, p. 808.

${ }^{19}$ Abdel Haleem, 'The Role Of Context In Interpreting and Translating The Qur'an', Journal Of Qur'anic Studies, 20.1 (2018), p. 47.

${ }^{20}$ Zayyanu Altine, 'Brief Life History and The Views Of Shaykh Abd Allah Bin Foduye and Bediuzzaman Said Nursi On The I'jaz Al Qur'an', Saudi Journal Of Humanities and Social Sciences, 3.7 (2018), p. 834.

${ }^{21}$ Said An Noursi, Al Maktūbât (Istanbul: Sozler, 1992), pp. 508-9.
} 
composition of Al-Qur'an which consists of letters, words and sentences, interrelated with one another. The letters, words and sentences in the editorial composition of AlQur'an cannot be replaced by anything else. For this reason, why Al-Qur'an cannot be narrated in a meaningful manner, as the Hadith is permitted to be narrated in a meaningful way, due to changes or the replacement of one letter, words or even sentences in the composition of the Al-Qur'an, can eliminate the miracle aspects.

The essence of the miracle of Al-Qur'an is its quality, not the quantity aspect. The challenge to bring such a Qur'an is to bring such a Al-Qur'an in terms of the quality it has, not on the quantity. The inability of humans and jinn to bring such as Al-Qur'an is to bring something like the quality of Al-Qur'an. The breadth and depth of meaning contained in each letter, word and sentence of Al-Qur'an is what makes people amazed with the language of Al-Qur'an, this phenomenon is part of the Quran, where Al-Qur'an is sufficient by using the editorial very briefly, to describe a very broad and deep message.

As a concrete example of how the existence of a single word in the editions of AlQur'an cannot be replaced, and its existence can provide proof of its truth, is the existence of the letter Ta At Ta nîts (which shows the female gender) in the sentence Qālat Namlatun Yā Ayyuha An Naml Udkhuluū Masākinakum (said an ant, a female to another ant group, enter you into your nests, ${ }^{22}$ this phenomenon is confirmed by scientific facts, that the truth is true communication occurs routinely between the ant community and that the ants with the female sex are the queens and leaders in a group, and not of the male gender. ${ }^{23}$

Some concrete examples of the phenomenon of the Al-Qur'an written by An Noursi in his book are: First, the existence of pieces of hija'iyyah letters at the beginning of several surah of Al-Qur'an, such as: Alif Lâm Mîm at the beginning of surah Al Baqarah. ${ }^{24}$ In observation An Noursi, there are many meanings that can be presented, and it becomes the secret of the existence of hija'iyyah letters at the beginning of several surah in Al-Qur'an. The meanings are as follows:

${ }^{22}$ Al Qur'an, v. Q.S. An Naml [27]: 18.

23 'Kini Bisa Dibuktikan, Kata Al Qur'an Tentang Semut Berbicara', Tribun-Timur.Com, 18 April 2015, no. 18 April 2015 <https://makassar.tribunnews.com/amp/2015/04/18/kini-bisa-dibuktikan-kata-alquran-tentang-semut-berbicara>.

${ }^{24}$ Al Qur'an, v. Q.S. Al Baqarah [2]: 1. 
Pieces of hija'iyyah letters such as Alif Lâm Mîm shows that these words are Azali (existing before others), which was revealed by the angel Gabriel to the prophet Muhammad. This piece of hija'iyyah is a kind of God's secret given to His Messenger, and only His Messenger has the secret key, where no human with his mind can open the secret. Pieces of hija'iyyah letters indicate the intelligence of the figure revealed to him these hija'iyyah letters, due to his ability to be able to understand sign language, as he understands straightforward and bright language.

These hija'iyyah letters indicate that the quality of a letter not only lies in its meaning, because there are a number of secrets that can be revealed behind the existence of these hija'iyyah letters. In fact, Alif Lâm Mîm specifically, this piece of the hija'iyyah letter suggests the existence of three Makhârij Al Hurūf (the place where the letters came out), namely: esophagus, tongue and lips. ${ }^{25}$ An Noursi's interpretation above about the of hija'iyyah letters at the beginning of a number of surah in Al-Qur'an, is very progressive compared to a number of other scholars who say that the meaning of the letter cuts is only Allah who knows them. ${ }^{26}$

Second, the word of Allah SWT Wa Mimmâ Razaqnâhum Yunfiqūn. ${ }^{27}$ In An Noursi's view, careful reading of this verse can conclude five (5) conditions that must be considered and fulfilled by someone, so that the donation is received by Allah SWT. The word Min is taken from the word Mimmâ and shows meaning: in part. This word reminds a person not to overdo in the act, especially because of excessive infaq, they need someone else's infaq in the future to cover their daily needs. Razaqnâhum said in the above verse, reminding us that the assets we share must be our possessions, not those of others. In other words: Do infaq with what Allah gives to you, not with the fortune of others.

The pronoun Nâ on Razaqnâhum indicates that the owner of the intrinsic wealth in humans is Allah Almighty. When someone give infaq for someone else, he truly gives with the wealth of his God not from his wealth. So do not be arrogant when humans give infaq to others or when those people expect too much for rewards from humans because they already give infaq. The word Yunfiqūn requires those who are sincere in giving their wealth partially in the right way, not for things that are not useful, especially committing

\footnotetext{
${ }^{25}$ Said An Noursi, Isyârât Al I jâzz Fî Mazhân Al Ijâzz (Istanbul: Sozler, 1994), p. 43.

26 Syamsu Nahar, 'Keberadaan Ayat Muhkam Dan Mutasyabih Dalam Al Qur'an', Jurnal Nizhamiyah, VI.2 (2016), pp. 11-12.

${ }^{27}$ Al Qur'an, v. Q.S. Al Baqarah [2]: 3.
} 
sin. The word Razaqnâhum in the above verse also reminds people to act in the name of their God, because truly the treasure belongs to his God, then act in the name of God, the true owner of the treasure.

Those are some of the meanings that can be examined about how someone's infaq could be accepted, referring to the Wa Mimmâ Razaqnâhum Yunfiqūn verse. Just as this verse implies a number how someone's infaq could be accepted, this verse also implies to us that the infaq has a broad dimension in, including infaq with assets, infaq with knowledge, or even infaq with words and deeds, this refers to the election the word Mâ in Mimmâ which shows the generality of meaning. Moreover, so the editorial of this verse itself is Muthlaq (unlimited). ${ }^{28}$

Third, the phenomenon of the $\hat{\imath} j \hat{a} z$ of Al-Qur'an is also clearly seen when AlQur'an describes a number of historical facts through the verses of the story. Such as: $W a$ Qîla Yâ Ardhubla `î Mâ'aki Wa Yâ Samâ'u Aqli î Wa Ghîdha Al Mâ'u Wa Qudhiya Al Amru Wa Istawat 'Alâ Al Jüdiyyi Wa Qîla Bu' and Li Al Qaumi Azh Zhālimîna (And it was said, "O earth, swallow your water, and O sky, withhold [your rain]." The commandment was completed and the ship was anchored on the mountain of gambling, and it was said "Away with the wrongdoing people". ${ }^{29}$ The verse above is a snippet from the story of the flash flood that befell the people of Noah as, how the end of the flash flood is described in its entirety by Al-Qur'an in the above verse using a very short editorial, something that makes the language experts impressed with him. ${ }^{30}$

\section{Implications of the Theory of $\hat{\jmath} j \hat{a} z$ Towards Al Qur'an Translation}

The theory of the $\hat{\jmath} j a \hat{z}$ in Al Qur'an as proposed by An Noursi is the depth and breadth of the content of the meaning of Al-Qur'an in a very short and accurate editorial. Inevitably, the theory of the $\hat{\imath} j \hat{a} z$ influences An Noursi's perspective of the translation of Al-Qur'an. In connection with the translation of Al-Qur'an, Ulama (theologian) themselves are divided into two groups. First, groups who forbid the translation of AlQur'an, in their perspective the product of the translation of Al-Qur'an will open space for Al-Qur'an to be blasphemed by its critics, because there is no language outside the language of Al-Qur'an that can transfer intact content of meaning which is owned by the

\footnotetext{
${ }^{28}$ An Noursi, Al Maktūbât, pp. 427-28.

${ }^{29}$ Al Qur'an, v. Q.S. Hūd [11]: 44.

${ }^{30}$ An Noursi, Al Maktūbât, p. 408.
} 
language of Al-Qur'an. As Al Qur'an translation products will reduce the miracle of AlQur'an itself. ${ }^{31}$

Instead the second group allows the translation of Al-Qur'an. In their view, translating Al-Qur'an is very urgent to do and intended especially for non-Arabs, in order to bring them closer to the meaning of Al-Qur'an. In the context of Indonesianism, discussing about Al-Qur'an into Indonesian is one of the efforts to promote Al-Qur'an in the midst of Indonesian society. ${ }^{32}$ Reading the An Noursi's perspective of the translation of Al-Qur'an, in the writer's opinion, An Noursi is more fitting to be grouped with the first group, because his views about the translation of Al-Qur'an are in line with the perspective of the first group which forbids the translation of Al-Qur'an.

The translation of Al-Qur'an in An Noursi's perspective is a plot and poison sought by the enemies of Islam, in order to degrade the majesty of Al-Qur'an. As with the existence of the product of the translation of Al-Qur'an, it is hoped that people will prefer to read the translation rather than reading the original text. Al-Qur'an cannot be translated in its entirety, because any language is incapable of maintaining and preserving the excess aspects of the language possessed by Al-Qur'an language. Any translation produced by humans to Al-Al-Qur'an text cannot replace the position of AlAl-Qur'an text with all the excess language possessed by each letter. For this reason, it is not possible to read the translation of Al-Qur'an replacing the position of reading the original text of Al-Qur'an. ${ }^{33}$

Looking at the two views of the two groups above, it would be better to put first the essence of the word "translation" itself. The word "translation" has two (2) meanings: First, translating means a process of transferring words from one language to another without explanation, by concerning to the suitability of all aspects, the transfer in a translation like this is only in the lafazh not in its meaning, such translation is known as the Tarjamah Harfiyyah. Second, translation is interpreted as an interpretation of words in other languages. Such a translation does not pay attention to the order and order of the words of the language to be translated as in the first translation, nor does it require

${ }^{31}$ Egi Sukma Baihaqi, 'Penerjemahan Al Qur'an: Proses Penerjemahan Al Qur'an Di Indonesia', Jurnal Ushuluddin, 25.1 (2017), p. 48.

${ }^{32}$ Muhammad Chirzin, 'Dinamika Terjemah Al-Qur'an (Studi Perbandingan Terjemah al-Qur'an Kementerian Agama RI Dan Muhammad Thalib)', Jurnal Studi Ilmu-Ilmu al-Qur'an Dan Hadis, 17.1 (2016), p. 7.

${ }^{33}$ Said An Noursi, Al Kalimât (Istanbul: Sozler, 1992), p. 538. 
conformity in all aspects, because this translation is limited to an interpretation and explanation. Such translations are known as Tarjamah Tafsîriyyah. ${ }^{34}$

With regard to the two versions of the translation above, with all the differences between the two, we can say: First, Tarjamah Tafsīiyyah of Al-Qur'an text is permissible, because such translations are only interpretations, there is no difference between this translation and other works of interpretation of Al-Qur'an. A work of interpretation of Al-Qur'an is only a work that seeks to explain what is meant from a word of Allah in Al-Qur'an limited to the ability of humans to interpret it. ${ }^{35}$ And translations like this at all and should not be considered to have represented the whole the meaning contained in the text of Al-Qur'an. Because each language (source language and target language) in addition to having its own characteristics, sometimes each expression has a meaning that contains its own nuances. ${ }^{36}$

Second, Tarjamah Harfiyyah may not be applied to the text of Al-Qur'an, because Al-Qur'an is a collection of the words of Allah Almighty revealed to His Messenger, contains miracles in lafazh and their meanings, and is worth worship for those who read them. Nobody says that the product of translating Al-Qur'an is the word of Allah, because Allah does not speak except in the language of Al-Qur'an, as the miraculous aspects of Al-Qur'an cannot be presented through its translation. Third, the difference between the two groups above regarding the translation of Al-Qur'an is limited to differences in perspective in interpreting the translation and not substantive. Because of the reasons put forward by the group who reject the translation of Al-Qur'an, it can only be said to be correct if it is addressed to the Tarfiqah Harfiyyah. As the purpose of the translation allowed by the group that allows the translation of Al-Qur'an is Tarjamah Tafsîriyyah.

More than that, in order to produce a correct translation and minimize errors, a Tarjamah Tafsīriyyah of Al-Qur'an text must also consider as follows: First, combining the text of Al-Qur'an with the translation of the text on the same page. Second, the translation process should be under the supervision of a number of parties who have competence and credibility. Third, individuals involved in the translation process should

\footnotetext{
${ }^{34}$ Islah Gusmian, 'Karakteristik Naskah Terjemahan Al Qur'an Pegon Perpustakaan Masjid Agung Surakarta', Jurnal Șuhuf, 5.1 (2012), 64 (p. 64).

35 Ready Musholli, 'Arus Baru Kecenderungan Penafsiran Kontemporer', Jurnal Of Qur'ân and Hadîts Studies, 1.1 (2012), 104 (p. 104).

${ }^{36}$ Rizqa Ahmadi, 'Model Terjemahan Al Qur'an Tafsiriyah Ustad Muhammad Thalib', Jurnal CMES (Center Of Middle Eastern Studies), VIII.1 (2015), p. 60.
} 
have good language competence. Fourth, translating the product as far as possible is kept away from terms or complicated scientific discussions. Fifth, the product of translating Al-Qur'an should not be shackled by the opinion of one particular school of thought.

By harmonizing the views of the two groups above about the translation of AlQur'an, while in practice, things that must be considered in a translation of Al-Qur'an are also guided, in our opinion, the resistance surrounding the translation of Al-Qur'an will disappear. As An Noursi's rejection of the translation of Al-Qur'an, in our opinion what is meant by this rejection is Tarjamah Harfiyyah. Due to the similarity of the arguments presented by An Noursi and groups who reject the translation of Al-Qur'an. As An Noursi's strong perspective of the translation of Al-Qur'an above, is actually addressed to a group in Turkey who often echoes the translation of Al-Qur'an into Turkish with Tarjamah Harfiyyah, and the use of the translation product in daily worship rituals, such as: prayer and reading rituals of Al-Qur'an ${ }^{37}$ After the collapse of the Uthmaniyyah caliphate and the change of status of Turkey into a republic, under the leadership of Mutafa Kamal who carried the principles of secularism, modernism and nationalism. ${ }^{38}$

As for the Tarjamah Tafsīriyyah regarding the text of Al-Qur'an, even though An Noursi did not directly discuss it, we believe that he agrees with the group that allows it, as long as the process is in accordance with the provisions and considers the precautionary aspects required by the Ulama, in the context of keep the text of Al-Qur'an from all attempts to distort it. As Islamic $d a^{\prime} w a h$ is a universal $d a^{\prime} w a h$, and the existence of Tarjamah Tafsitriyyah on Al-Qur'an texts in various languages of the world, is an important part of the media for the success of Islamic da'wah itself.

\section{Conclusion}

The Ulama agreed to make aspects of the language of Al-Qur'an as its miraculous aspect. And the phenomenon of Al $\hat{I j} \hat{a} z$ (short editors with the depth of meaning they have), is one important part of the elements of Al-Qur'an language. For this reason, the effort to transfer the full meaning of Al-Qur'an is an impossibility, because there are a number of advantages and features in Arabic that are used in Al-Qur'an, which are not owned by Arabic or other languages used in human works. An Noursi, one of the Ulama who studied the side of $\hat{I j} \hat{a} z$ in Al Qur'an, is a figure of Ulama who strongly rejects

\footnotetext{
${ }^{37}$ An Noursi, Al Maktūbât, p. 559.
} 
efforts to keep people from interacting with the original text of Al-Qur'an through its translation. However, this refusal is in our opinion, when the intended translation product is Tarjamah Harfiyyah instead of Tarjamah Tafsîriyyah, especially to later make this Tarjamah Harfiyyah product as a substitute for Al-Qur'an in a ritual of worship. The hope of the author, efforts to conduct further in-depth research related to $\hat{\imath} j \hat{a} z$ of AlQur'an in the perspective of An-Noursi and its implications for the translation of AlQuran.

\section{Acknowledgment}

Thanks to Lajnah Pentashihan Mushaf Al Qur'an (Ratification Committee of AlQur'an Manuscripts), the Ministry of Religious Affairs, Republic of Indonesia, which has involved to be part of the process of perfecting Al-Qur'an and its translation into Indonesian, both as speakers and discussants, for this activity, the author was inspired to write a paper about the translation of Al-Qur'an.

\section{References}

Abdurrahman, 'Mukjizat Al Qur'an Dalam Berbagai Aspeknya', Jurnal Pusaka, 8 (2016)

Ahmad, Sa'ad, 'I'jâz Al Qur'ân 'Inda An Nursî Mafâhîm Wa Zhawâbith', The Journal Of Risale-i Nur Studies, 1.1 (2018)

Ahmadi, Rizqa, 'Model Terjemahan Al Qur'an Tafsiriyah Ustad Muhammad Thalib', Jurnal CMES (Center Of Middle Eastern Studies), VIII.1 (2015)

Al Qur'an (Jakarta: Kemenag RI, 2018)

Al Qurthubi, Abdullah, Al Jâmi`Li Ahkâm Al Qur'ân (Cairo: Dar Al Hadits, 2010), I

Ali, Mohd Safri, 'Said Nursi's Theological Thoughts In The Light Of Sunni Doctrine', Pertanika Journal (Social Sciences \& Humanities), 25 (2017)

Altine, Zayyanu, 'Brief Life History and The Views Of Shaykh Abd Allah Bin Foduye and Bediuzzaman Said Nursi On The I'jaz Al Qur'an', Saudi Journal Of Humanities and Social Sciences, 3.7 (2018)

An Noursi, Said, Al Kalimât (Istanbul: Sozler, 1992)

, Al Maktūbât (Istanbul: Sozler, 1992)

38 Tabrani, 'Perubahan Ideologi Keislaman Turki (Analisis Geo-Kultur Dan Politik Pada Kerajaan Turki Usmani)’, Jurnal Edukasi (Media Kajian Bimbingan Konseling), 2.2 (2016), p. 132. 
, Isyârât Al I jâz Fî Mazhân Al Îjâz (Istanbul: Sozler, 1994)

As Suyuthi, Jalaluddin, Al Itqân Fî̀ 'Ulūm Al Qur'ân (Damaskus: Dar Ibnu Katsir, 2000), II

Baihaqi, Egi Sukma, 'Penerjemahan Al Qur'an: Proses Penerjemahan Al Qur'an Di Indonesia', Jurnal Ushuluddin, 25.1 (2017)

Chirzin, Muhammad, 'Dinamika Terjemah Al-Qur'an (Studi Perbandingan Terjemah alQur'an Kementerian Agama RI Dan Muhammad Thalib)', Jurnal Studi Ilmu-Ilmu al-Qur'an Dan Hadis, 17.1 (2016)

Gusmian, Islah, 'Karakteristik Naskah Terjemahan Al Qur'an Pegon Perpustakaan Masjid Agung Surakarta', Jurnal Șuḥuf, 5.1 (2012), 64

Haleem, Abdel, 'The Role Of Context In Interpreting and Translating The Qur'an', Journal Of Qur'anic Studies, 20.1 (2018)

Hilal, Mahir, 'Dirâyat al I'jâz Inda Fakhriddin al Râzi', Quranica: International Journal Of Quranic Research, 7a.Special Issue (2015)

Laila, Izzatul, 'Penafsiran Al Qur'an Berbasis Ilmu Pengetahuan', Jurnal Epistemé, 9.1 (2014)

Masbukin, 'Kemu’jizatan Al Qur'an, Jurnal Pemikiran Islam', Jurnal Pemikiran Islam, $37.2(2012)$

Muhammad, Ali, 'Qur'anic Scientism In Bediuzzaman Said Nursi's Risala-I-Nur', Qudus International Journal Of Islamic Studies, 5.1 (2017)

Muhammad, Azhar, 'Beberapa Aspek Keunikan Dan Keistimewaan Bahasa Arab Sebagai Bahasa Al Qur'an', Jurnal Teknologi, 42 (2005)

Muhammad, Hilmy, 'Nazhm Al Qur'an Dalam Perspektif Syihab al-Dīn al-Alūsī', Jurnal Refleksi, 13.6 (2014)

Musholli, Ready, 'Arus Baru Kecenderungan Penafsiran Kontemporer', Jurnal of Qur'ân and Hadîts Studies, 1.1 (2012), 104

Nahar, Syamsu, 'Keberadaan Ayat Muhkam Dan Mutasyabih Dalam Al Qur'an', Jurnal Nizhamiyah, VI.2 (2016)

Syed, Sharifah, and Ahmed Al Qodsi, 'The Manifestation Of Miraculous Effects Of The Quran On The Creatures From The Perspective Of Al-Quran, Hadits and Science', Quranica: International Journal Of Quranic Research, 9.2 (2017)

Tabrani, 'Perubahan Ideologi Keislaman Turki (Analisis Geo-Kultur Dan Politik Pada Kerajaan Turki Usmani)', Jurnal Edukasi (Media Kajian Bimbingan Konseling), $2.2(2016)$ 
Thabrani, Ach, 'Nadzam Dalam I'jaz Al Qur'an Menurut Abdul Qahir Al Jurjani', Jurnal Al Mi yar, 1.1 (2018)

Yusoff, Kamaruzzaman, 'Transition In Turkey: An Overview Of Badiuzzaman Said Nursi, His Life and Works For Medresetu'z-Zehra', International Journal of West Asian Studies, 5.2 (2013)

Zaka, Mohamad, 'Aspek Relevansi Dalam Terjemahan Tindak-Tutur Kinâyah Al Qur'an', Jurnal Karsa (Journal Of Social and Islamic Culture), 21.2 (2013)

Zubair, Hamid, 'Muslim Response To The West: A Comparative Study Of Muhammad Abduh and Said Nursi', Journal Of Islamic Thougt and Civilization, 4.2 (2014) 